\title{
Estrogen Receptor (ER) $\beta$ Isoforms Rather Than ER $\alpha$ Regulate Corticotropin-Releasing Hormone Promoter Activity through an Alternate Pathway
}

\author{
William J. Schouler Miller, ${ }^{1,2}$ Shotaro Suzuki, ${ }^{3}$ Lydia K. Miller, ${ }^{1,2}$ Robert Handa, ${ }^{3}$ and Rosalie M. Uht ${ }^{1}$ \\ ${ }^{1}$ Departments of Pathology and Biochemistry and Molecular Genetics and ${ }^{2}$ University of Virginia College, University of Virginia, Charlottesville, Virginia \\ 22908-0904, and ${ }^{3}$ Colorado State University, Fort Collins, Colorado 80523
}

\begin{abstract}
The hypothalamic-pituitary-adrenal axis regulates mammalian stress responses by secreting glucocorticoids. The magnitude of the response is in part determined by gender, for in response to a given stressor, circulating glucocorticoids reach higher levels in female rats than in males. This gender difference could result from estrogen regulation of the corticotropin-releasing hormone (CRH) promoter via either of its receptors: estrogen receptor (ER) $\alpha$ or ER $\beta$. Immunocytochemistry revealed that a subset (12\%) of medial parvocellular CRH neurons in the rat hypothalamus contain $\operatorname{ER} \beta$ but not $\operatorname{ER} \alpha$. To determine whether ERs could regulate CRH promoter activity, we cotransfected cells with a CRH promoter construct and either $\mathrm{ER} \alpha$ or individual ER $\beta$ isoforms. ER $\alpha$ weakly stimulated CRH promoter transcriptional activity in a ligand-independent manner. Conversely, all ER $\beta$ isoforms tested stimulated CRH promoter activity with different ligand profiles. ER $\beta 1$ and $\operatorname{ER} \beta 2 \delta 3$ displayed constitutive activity (ER $\beta 1$ more than ER $\beta 2 \delta 3)$. Ligand-dependent activity of $\beta$ isoforms 1 and 2 was altered by an Exon 3 splice variant $(\delta 3)$ or by the additional 18 amino acids in the ligand-binding domain of ER $\beta 2$ isoforms. Lastly, we suggest that ER regulation of CRH takes place through an alternate pathway, one that requires protein-protein interactions with other transcription factors or their associated complexes. However, a pure ER-activator protein-1 alternate pathway does not appear to be involved.
\end{abstract}

Key words: estrogen receptor $\alpha$; estrogen receptor $\beta$; corticotropin-releasing hormone; estradiol; tamoxifen; stress

\section{Introduction}

Although a consensus opinion does not exist as to the definition of "stress," it is accepted that a stimulus that activates the hypothalamic-pituitary-adrenal axis (HPAA) is a stressor (Pacak and Palkovits, 2001). HPAA activation leads to adrenal glucocorticoid secretion, which in turn downregulates the axis. States in which glucocorticoids are chronically elevated or the axis is inappropriately downregulated are pathologic. For example, the inability of dexamethasone to downregulate the HPAA in humans correlates with depression (Gold et al., 1986a), and HPAA dysregulation is associated with anorexia nervosa (Gold et al., 1986b). Both of these disorders have a female preponderance (Brotman, 2001; Wulsin, 2001). HPAA gender differences are also present in the rat: females secrete higher levels of adrenocorticotropin and glucocorticoids in response to a stressor than males, and

\footnotetext{
Received June 4, 2003; revised Sept. 16, 2004; accepted 0ct. 7, 2004.

This work was funded by National Institutes of Health Grant R01 NS39951 (R.H., R.M.U.) and by a Young Investigator Award from the National Alliance for Research on Schizophrenia and Depression to R.M.U., a 2003 Lieber Investigator. CRH:LUC was a generous gift from Audrey Seasholtz (University of Michigan, Ann Arbor, MI). Emilie Rissman assisted with statistical analysis.

Correspondence should be addressed to Dr. Rosalie M. Uht, Department of Pathology, MR5, Room 3123, 415 Lane Road, University of Virginia School of Medicine, P.0. Box 800904, Charlottesville, VA 22908-0904. E-mail: ruht@virginia.edu.

W. J. S. Miller's present address: University of Virginia School of Medicine, Charlottesville, VA 22908-0904.

S. Suzuki's present address: University of California Davis, Davis, CA 95616.

DOl:10.1523/JNEUROSCI.5540-03.2004

Copyright $\odot 2004$ Society for Neuroscience $\quad$ 0270-6474/04/2410628-08\$15.00/0
}

this difference tracks to circulating estrogens (Burgess and Handa, 1992). Therefore, estrogens may interfere with glucocorticoidmediated downregulation and/or facilitate HPAA activation.

Hypothalamic paraventricular parvocellular neurons integrate sensory and hormonal inputs. These neurons synthesize and secrete corticotropin-releasing hormone (CRH) (Vale et al., 1981 ) in response to numerous stimuli (for review, see Pacak and Palkovits, 2001). Because CRH neurons contain glucocorticoid receptors (GR) (Cintra et al., 1987; Liposits et al., 1987; Uht et al., 1988), and because glucocorticoids downregulate cAMPactivated CRH transcription (Guardiola-Diaz et al., 1996), it may be that a component of downregulation occurs at the level of CRH transcription.

The estrogen receptor (ER) immunocytochemical status of $\mathrm{CRH}$ neurons has not been well established. At the level of mRNA, however, ER $\alpha$ and ER $\beta$ have strikingly different distributions (Shughrue et al., 1997). In contrast to $\mathrm{ER} \alpha$, ER $\beta$ mRNA is abundant in the rat paraventricular nucleus of the hypothalamus (PVH). Also, immunoreactive (IR) ER $\beta$ is present in mouse parvocellular neurons (Mitra et al., 2003). Because ER $\beta$ mRNA has been detected in rat IR CRH neurons (LaFlamme et al., 1998), and IR ER $\beta$ has been reported in mouse paraventricular nuclei (PVNs) (Mitra et al., 2003), we first asked whether IR ER $\beta$ colocalized with IR CRH in the rat PVH.

ER $\beta$ exists in several splice variants (see Fig. $1 B$ ) (Petersen et al., 1998; Price et al., 2000), with ER $\beta 1$ being the first described. 
$\mathrm{ER} \beta 2$ contains 18 additional amino acids in the ligand-binding domain (LBD) (Petersen et al., 1998). 83 isoforms lack the DNAbinding domain (DBD) second zinc finger (see Fig. $1 B$ ) (Petersen et al., 1998). Because multiple ER $\beta$ isoforms are present in the rat PVH (Price et al., 2000), differential expression could permit a spectrum of estrogen responses.

Agonist-bound ER $\alpha$ s and ER $\beta$ s bind palindromic estrogen response elements (EREs) and then activate transcription. Paradoxically, none of these full EREs are present in the CRH promoter, although ERE half-sites are present (Vamvakopoulos and Chrousos, 1993). ERs also regulate transcription via alternate pathways. For example, $\mathrm{ER} \alpha$ and $\mathrm{ER} \beta 1$ stimulate activator protein-1 (AP-1) activity (Gaub et al., 1990; Umayahara et al., 1994; Webb et al., 1995; Paech et al., 1997) but with different ligand profiles: agonist- and antagonist-bound ER $\alpha$ stimulate AP-1 transcriptional activity, whereas only antagonist-bound ER $\beta$ stimulates this activity (Paech et al., 1997). Given the importance of alternate pathways and the diversity of $\operatorname{ER} \beta$ variants, we asked whether $\mathrm{ER} \beta$ and its isoforms could differentially regulate CRH promoter transcriptional activity.

\section{Materials and Methods \\ Animals}

Animal protocols were approved by the Animal Care and Use Committee of Colorado State University (Fort Collins, CO). Five young adult female Sprague Dawley rats (200-250 gm) were purchased from Charles River Laboratories (Portage, MI). Animals were acclimated to laboratory conditions (12 hr light/dark cycle) with food and water available ad libitum. For immunocytochemical studies, animals were anesthetized with sodium pentobarbital $(50 \mathrm{mg} / \mathrm{kg})$ and placed into a stereotaxic apparatus (David Kopf Instruments, Tujunga, CA). Colchicine (10 $\mu \mathrm{l} \mathrm{of} \mathrm{a} 10 \mu \mathrm{g} / \mu \mathrm{l}$ solution) was infused into the third ventricle through a Hamilton syringe over a period of 4-5 min. Animals were kept alive for another $18-24 \mathrm{hr}$ and were then perfused with $0.9 \%$ saline followed by $10 \%$ neutral buffered formalin. For PCR analysis, animals were female Sprague Dawley rats (200-250 gm) purchased from Charles River Breeding Laboratories. Animals were bilaterally ovariectomized $3 \mathrm{~d}$ before they were killed. This procedure was used to upregulate the expression of ER $\beta$ in the PVH, because previous studies have shown that ER $\beta$ mRNA is downregulated after estrogen treatment (Tx) (Osterlund et al., 1998; Patisaul et al., 1999; Suzuki and Handa, 2004).

\section{Immunocytochemistry}

Tissue preparation. Brains were postfixed for $2 \mathrm{hr}$ at room temperature, placed in $5 \%$ neutral buffered formalin-15\% sucrose in $0.1 \mathrm{M}$ PBS overnight at $4^{\circ} \mathrm{C}$, and then transferred to $30 \%$ sucrose in $0.1 \mathrm{M} \mathrm{PBS}$ at $4^{\circ} \mathrm{C}$ until permeated. This fixation procedure was found to provide the most robust ER $\beta$ immunostaining when compared with $4 \%$ paraformaldehyde and $2 \%$ acrolein fixation. Thus, this procedure was used throughout. Subsequently, the tissues were cut on a cryostat at $35 \mu \mathrm{m}$ and saved in 0.1 м PBS- $0.1 \%$ sodium azide at $4^{\circ} \mathrm{C}$ until processed, as described above.

Double-label immunohistochemistry. The following antibodies and dilutions were used: ER $\beta$ (Z8P; 1:4000; Zymed Laboratories, San Francisco, CA), CRH (1:25,000; from Dr. Wylie Vale, The Salk Institute, La Jolla, CA), and ER $\alpha$ (C1355; 1:10,000; from Dr. M. Shupnik, University of Virginia, Charlottesville, VA).

Tissue sections were processed as described previously (Kerr et al., 1995). Tissue was washed in $0.1 \mathrm{M}$ PBS with $0.1 \%$ Triton X-100 (TX) and incubated with $0.3 \% \mathrm{H}_{2} \mathrm{O}_{2}$ in $0.1 \mathrm{M}$ PBS with $0.1 \%$ TX to quench endogenous peroxidase activity. After washes, sections were incubated in $6 \%$ normal goat serum (NGS) in $0.1 \mathrm{~m}$ PBS with $0.1 \%$ TX to block nonspecific binding and then incubated for $48 \mathrm{hr}$ at $4^{\circ} \mathrm{C}$ with $\mathrm{ER} \alpha$ or ER $\beta$ antiserum in $0.1 \mathrm{M}$ PBS with TX and 2\% NGS. Next, the tissue was washed and incubated with biotinylated goat anti-rabbit IgG (1:500; Vector Laboratories, Burlingame, CA) in PBS with TX and 2\% NGS for $2 \mathrm{hr}$ at room temperature. Sections were processed according to the $\mathrm{ABC}$ procedure (1:500; Vector Laboratories). The tissue was rinsed in $0.1 \mathrm{~m}$ Tris-buffered saline and then developed with nickel-intensified 3,3'-diaminobenzidine (DAB) $(0.5 \mathrm{mg} / \mathrm{ml}$; Sigma, St. Louis, MO) in $0.1 \mathrm{~m}$ Tris-buffered saline containing $0.03 \%$ hydrogen peroxide. The reaction was stopped by washes in $0.1 \mathrm{M}$ PBS.

Subsequently, the tissue was processed for CRH immunoreactivity. The procedure was as above, except that primary antibody incubation was for $72 \mathrm{hr}$ at $4^{\circ} \mathrm{C}$. Sections were developed with DAB $(0.5 \mathrm{mg} / \mathrm{ml}$ with $0.03 \%$ hydrogen peroxide) to produce a brown reaction product. Samples were examined with a Zeiss (Thornwood, NY) Axioplan 2 microscope. Double-labeled neurons had a dark blue-black nucleus (IR ER $\beta$ ) and brown cytoplasm and nerve fibers (CRH immunoreactivity).

Methods for counting cells. Tissue sections were analyzed using a Zeiss Axioplan 2 imaging universal microscope, and images were captured with a Zeiss AxioCam digital camera. From three rat brains, tissue sections ( $35 \mu \mathrm{m}$ thick) corresponding to bregma level -1.53 were chosen for analysis. At this level, $\mathrm{CRH}$ immunoreactivity was mainly seen in the medial parvocellular part, and $\operatorname{ER} \beta$ immunoreactivity was strong. The percentage of colocalization was determined by manually counting the number of cells positively labeled for ER $\beta$ and CRH. Double-labeled neurons were identified as cells containing a dark blue nucleus $(\mathrm{ER} \beta)$ and a brown cytoplasm and fibers $(\mathrm{CRH})$. Peptide-positive, ER $\beta$-negative neurons were identified as having a brown cytoplasm and a pale or unstained nucleus.

\section{Amplification of hypothalamic ER $\beta$ isoforms}

Total RNA isolation. For PVH microdissection, a micropunch technique was used that was similar to the protocol used by Palkovits et al. (1985), as modified by Price et al. (2000). Brain sections were cut frozen on a cryostat, thaw mounted onto glass slides, and kept at $-80^{\circ} \mathrm{C}$ until micropunching. Micropunching was accomplished with a blunted needle with a $0.5 \mathrm{~mm}$ diameter. Isolation of total RNA was performed according to the protocol of Chomczynski and Sacchi (1987). Punch-dissected tissues were pooled from two animals and immediately homogenized in a centrifuge tube containing $250 \mu \mathrm{l}$ of guanidinium isothiocyanate buffer (4 m guanidinium isothiocyanate, $0.5 \%$ sarcosyl, $25 \mathrm{~mm}$ sodium citrate, $\mathrm{pH} 7.0$, and $0.1 \mathrm{M} \beta$-mercaptoethanol). After phenol chloroformisoamyl alcohol extraction and ethanol precipitation, the RNA was reconstituted in RNase-free water, and concentration was measured with a spectrophotometer. Only samples with a 260:280 ratio of $>1.6$ were used.

Reverse transcription. Equal amounts of total RNA $(0.5 \mu \mathrm{g})$ were reverse transcribed using Moloney murine leukemia virus reverse transcriptase (Invitrogen, Rockville, MD) in the presence of oligo-dT primers, deoxyNTPs (100 mм each), first strand buffer [containing (in mM): 100 Tris $\mathrm{HCl}, 900 \mathrm{KCl}, 1 \mathrm{MgCl}_{2}$ ], and $2.5 \mathrm{~mm}$ dithiothreitol. The reverse transcription (RT) reaction was performed at room temperature for 10 min followed by a $10 \mathrm{~min}$ incubation at $44.2^{\circ} \mathrm{C}$. The reaction was terminated by denaturing reverse transcriptase at $95^{\circ} \mathrm{C}$ for $5 \mathrm{~min}$. RTgenerated cDNA samples were stored at $-20^{\circ} \mathrm{C}$ until PCR amplification.

$E R \beta$ primers. PCR primers for rat $\mathrm{ER} \beta$ were designed using commercially available software (Oligo, version 6.1; Molecular Biology Insights, Cascade, CO). Twenty-one base primers were developed on the basis of established GenBank sequence (accession number U57439). The ER $\beta$ primers spanned the known splice variants and thus could identify individual $\mathrm{ER} \beta$ splice variants in a single reaction. The forward primer position began at nucleotide 455 , and the reverse primer position began at nucleotide 1570. The predicted PCR product size was $1190 \mathrm{nt}$ for ER $\beta 2$, $1136 \mathrm{nt}$ for $\mathrm{ER} \beta 1,1073 \mathrm{nt}$ for $\mathrm{ER} \beta 2 \delta 3$, and $1019 \mathrm{nt}$ for $\mathrm{ER} \beta 1 \delta 3$.

Real-time PCR amplification. Real-time PCR was performed according to the protocols of Solum and Handa (2002). Briefly, hot-start PCR was performed using the LightCycler DNA Master SYBR Green mix (Roche Molecular Biochemicals, Indianapolis, IN). Samples were subjected to an initial melting step at $95^{\circ} \mathrm{C}$ for $2 \mathrm{~min}$ and amplified at 40 cycles $(\sim 5-10$ cycles beyond the beginning of the linear phase of amplification) of a $95^{\circ} \mathrm{C}$ melting step $(2 \mathrm{sec})$, a $66^{\circ} \mathrm{C}$ annealing step $(7 \mathrm{sec})$, and a $72^{\circ} \mathrm{C}$ elongation step $(48 \mathrm{sec})$. Samples without template were used as negative controls. After PCR amplification, samples were separated on a $1.5 \%$ agarose gel with an appropriate molecular weight size marker (Invitro- 
A
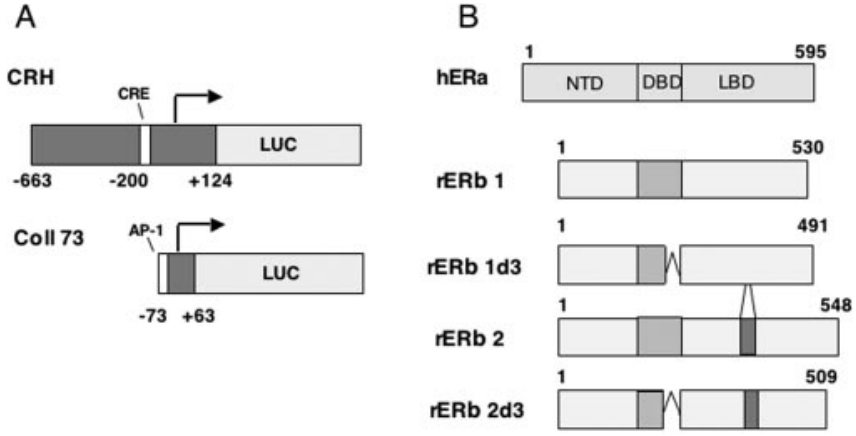

Figure 1. ER structures and reporter constructs. A, CRH and Coll73 promoter constructs used for transient transfections. The human CRH promoter fragment is $787 \mathrm{nt}$ long, 124 of which extend 3 ' to the start site (indicated by the arrow). The human collagenase promoter is a highly truncated collagenase promoter that has been used extensively to study ER regulation through the activator protein- 1 complex. $B$, Comparison of $E R \alpha$ and $E R \beta$ isoforms. All ER $\beta$ isoforms are shorter than $E R \alpha$ as a result of a truncated N-terminal domain (NTD). All ERs depicted occur naturally in the rat CNS at the level of mRNA. $h$, Human; $r$, rat.

gen) to ensure specificity of the PCR products. The agarose gel was stained using ethidium bromide and visualized under UV light.

\section{Transcription experiments}

Plasmids. All plasmids have been described previously (Fig. 1A). Reporter constructs were as follows: $[(-663)-(+124) \mathrm{CRH}]$ :luciferase (LUC) (Guardiola-Diaz et al., 1994) and human collagenase promoter (Coll73):LUC for AP-1 activity (Webb et al., 1995) (Fig. $1 A$ ); ER expression vectors were $\mathrm{ER} \alpha$ (Webb et al., 1995), $\mathrm{ER} \beta$, and $\mathrm{ER} \beta$ isoforms (Fig. $1 B$ ) (Price et al., 2001). Plasmids used to correct for efficiency of transfection were actin $\beta$-galactosidase or pJ3 (Uht et al., 1997).

Cells, cell culture, transfections, and treatments. HeLa cells were maintained in culture as described previously (Uht et al., 1997). Briefly, they were kept in phenol red-free DMEM (Sigma) supplemented with newborn calf serum (10\%) tested for low estrogenic activity (catalog \#100504; Gemini Bioproducts, Woodland, CA), penicillin (100 U/ml), and streptomycin $(100 \mu \mathrm{g} / \mathrm{ml})$ (Invitrogen). A total of 1,500,000 cells were transiently cotransfected with either 5 or $10 \mu \mathrm{g}$ of CRH:LUC and a range of $\operatorname{ER} \alpha$ and $\mathrm{ER} \beta$ expression vector quantities by electroporation, as described previously (Paech et al., 1997). $\beta$-Galactosidase plasmids were cotransfected to correct for the efficiency of transfection. Immediately after plating, cells were treated with ethanolic vehicle $(\mathrm{EtOH})$, estradiol (E2) (Sigma), or tamoxifen (Tmx) (Sigma) at $10^{-7}$ or $5 \times 10^{-6} \mathrm{M}$, respectively. On the day of harvest, each well was visually inspected to determine whether estradiol and/or tamoxifen had a marked effect on cell number or morphology. No discernable change in either was present. Cells were harvested $40-48 \mathrm{hr}$ after treatment.

Luciferase and $\beta$-galactosidase assays. Cells were lysed with cell lysis buffer (Promega, Madison, WI). Samples were analyzed for luciferase activity (Promega) and $\beta$-galactosidase activity via a light-emitting assay (Tropix, Bedford, MA). An MGM Optocomp II luminometer (MGM Instruments, Hamden, CT) was used to detect light emission.

Transfection data analysis. ER titration plus or minus ligand experiments: each receptor titration experiment was performed a minimum of three times. Txs were performed in triplicate or quadruplicate. To permit pooling data across experiments that would reflect both an effect of treatment and an effect of amount transfected, data values are expressed as a fold of the 0 ng point of a given treatment. In other words, the effect of treatment at a given amount of transfected ER was expressed relative to the effect of the treatment at $0 \mathrm{ng} \operatorname{ER}[\mathrm{Tx}(x \mathrm{ng}) / \mathrm{Tx}(0 \mathrm{ng})]$.

All receptor titration data (see Figs. 3-5) were analyzed by two-way ANOVAs. Unless otherwise specified, Bonferroni (all pairwise) multiplecomparison tests (Bonferroni tests) were performed to determine a difference within groups (Tx or nanograms of plasmid). The other test was a Fisher's least significant difference (LSD) multiple-comparison test. For the planned comparison tests, $\alpha$ was adjusted for the number of tests performed; data were deemed significant at $\alpha<0.050$. The data were analyzed twice: after the SD was calculated for all individual groups, points that were $\geq 2$ SD from the mean were discarded. ANOVAs and pairwise analyses were performed on the remaining data.

To compare $\mathrm{CRH}$ and Coll73 promoter responses to treatment in the presence of ER $\beta 1$ (see Fig. 6) and ER $\beta 2$ (data not shown), four tests of normality were first performed: skewness, kurtosis, omnibus normality of residuals, and a modified-Levene equal-variance test. If the data met normality criteria by three of the four tests, they were then analyzed by a one-way ANOVA, and pairwise comparisons were made using the Bonferroni test. If the data failed to meet normality criteria by two or more of the four tests, they were analyzed by a Kruskal-Wallis one-way ANOVA on ranks followed by the Kruskal-Wallis multiple-comparison $Z$ value test. All data analyses were performed using the Number Cruncher Statistical System program (NCSS, Kaysville, UT). Data are presented as means \pm SEM.

\section{Results \\ ER $\beta$ colocalizes with CRH in parvocellular neurons of the PVH}

We sought to determine whether ER protein colocalizes with $\mathrm{CRH}$ in medial parvocellular neurons using dual-label immunocytochemistry for ER $\beta$ and $\mathrm{CRH}$. Hypothalamic paraventricular parvocellular neurons have been shown to contain ER $\beta$ immunoreactivity in the mouse (Mitra et al., 2003). The PVH contained dual-labeled cells localized in the medial parvocellular region (Fig. 2 A). Colocalization of $\mathrm{CRH}$ with $\mathrm{ER} \beta$ (Fig. $2 \mathrm{~A}$, inset) was found in $12 \% \pm 2$ of $\mathrm{CRH}$ neurons. Such colocalization suggests that the receptor may play a role in regulating $\mathrm{CRH}$ transcription in certain physiologic or pathophysiologic states, at least in a subset of CRH-expressing neurons.

To determine whether the PVH contained ER $\beta$ isoforms, the Palkovits punch technique was used to obtain mRNA from ovariectomized rats. Amplification by RT-PCR revealed that ER $\beta 1$ and ER $\beta 2$ and their $\delta$ isoforms mRNAs were present (Fig. $2 B$ ). Amplified ER $\beta 2 \delta 3$ was consistently detected, albeit at low levels compared with the other three $\operatorname{ER} \beta$ isoforms. Given that antibodies specific to each isoform have not yet been successfully generated, we do not know whether they are also present at the protein level. However, the presence of their mRNA suggests that they may be.

To compare the localization of paraventricular ER $\beta$ to ER $\alpha$ in our experimental conditions, we performed CRH and ER $\alpha$ immunocytochemistry. IR $\operatorname{ER} \alpha$ was found only in a few hypothalamic paraventricular neurons scattered in the dorsal PVH; its distribution did not overlap that of $\mathrm{CRH}$ or $\mathrm{ER} \beta$ (Fig. 2, compare $D$ with $A, C)$. Together, these anatomical data indicate that $\mathrm{ER} \beta$ is the predominant ER in CRH-positive parvocellular neurons in the rat $\mathrm{PVH}$.

\section{ER $\alpha$ exerts modest effects on CRH promoter transcription}

The original study of ER regulation of the CRH promoter (Vamvakopoulos and Chrousos, 1993) was reported before the discovery of $\mathrm{ER} \beta$ (Kuiper et al., 1996). Using a $2.4 \mathrm{~kb} \mathrm{CRH}$ promoter, the authors concluded that $\mathrm{ER} \alpha$ stimulated the $\mathrm{CRH}$ promoter by twofold to threefold. Because ER $\alpha$ could be present in the CRH parvocellular neurons examined above but below the level of detection by the immunocytochemical techniques used, we asked whether ER $\alpha$ could regulate transcription of the CRH promoter in our conditions. We cotransfected HeLa cells with the CRH promoter construct (Fig. 1) and increasing amounts of the ER $\alpha$ expression vector. After plating, cells were treated with vehicle (EtOH), E2 $\left(10^{-7} \mathrm{M}\right)$, or Tmx $\left(5 \times 10^{-6} \mathrm{M}\right)$. A two-way ANOVA revealed a small effect of the amount of ER $\alpha$ transfected $\left(F_{(4,182)}=\right.$ 3.18; $p=0.0150$ ) (Fig. 3). There was no effect of treatment 
A

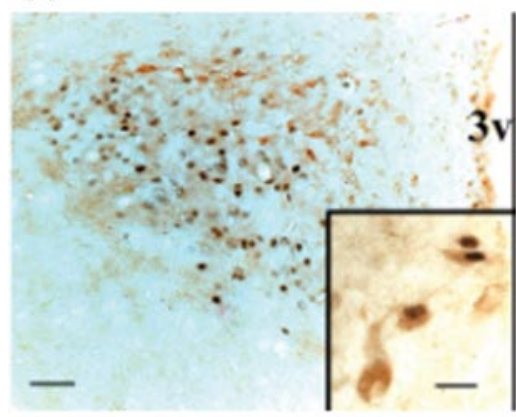

C

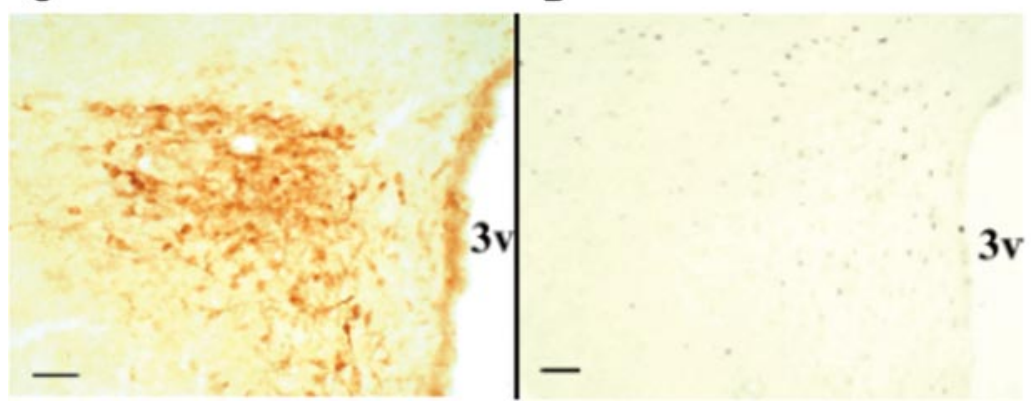

B

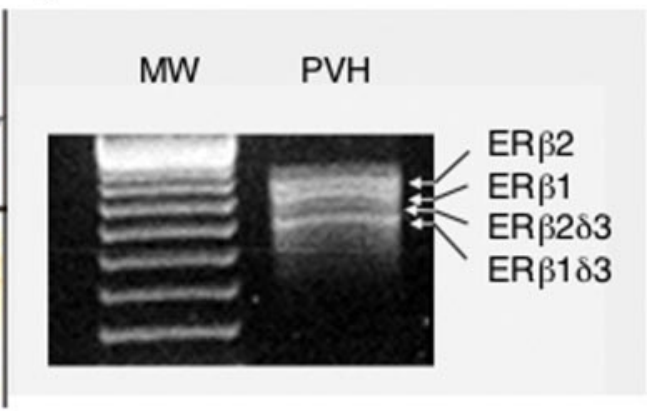

to $1 ; p<0.050)$. As a control, $\mathrm{ER} \alpha$ was transfected either with the CRH promoter:reporter construct or with the empty vector. Although the CRH promoter construct supported a small degree of activation, the corresponding signals for the vector control were all at the level of the mock transfection (data not shown). Thus, the effects we report here are mediated through the CRH promoter. The relatively small effects of $\mathrm{ER} \alpha$ at the $\mathrm{CRH}$ promoter are in accord with the data reported by Vamvakopoulos and Chrousos (1993). They showed a twofold to threefold increase in transcriptional activity elicited by E2 (Vamvakopoulos and Chrousos, 1993). Their data, together with the $\operatorname{ER} \alpha$ data presented here, suggest that $\mathrm{ER} \alpha$ plays a small but significant role in regulating the $\mathrm{CRH}$ promoter. Whether $\mathrm{ER} \alpha$ activation of the $\mathrm{CRH}$ promoter is ligand dependent or ligand independent likely depends on cell and promoter context.

Figure 2. IRER $\beta$ colocalizes with CRH immunoreactivity in the rat PVH. A, Colocalization of IRER $\beta$ (nuclear) and IRCRH (brown; cytoplasmic) in parvocellular neurons of colchicine-treated female rats. Scale bars: $A, 50 \mu \mathrm{m}$; inset, $15 \mu \mathrm{m}$. B, Gel electrophoretic analysis of RT-PCR products showing ER $\beta$ isoforms in total RNA taken from micropunched PVH of ovariectomized female rats. Arrows point to the different $E R \beta$ splice variant mRNAs. C, Single-labeling study showing CRH distribution in the PVH. D, The distribution of CRH immunoreactivity does not overlap that of IR ER $\alpha$ nuclei, which is weak and found predominantly in neurons adjacent to the PVH. Scale bars, C, D, $50 \mu \mathrm{m}$. 3v, Third ventricle; MW, molecular weight markers.

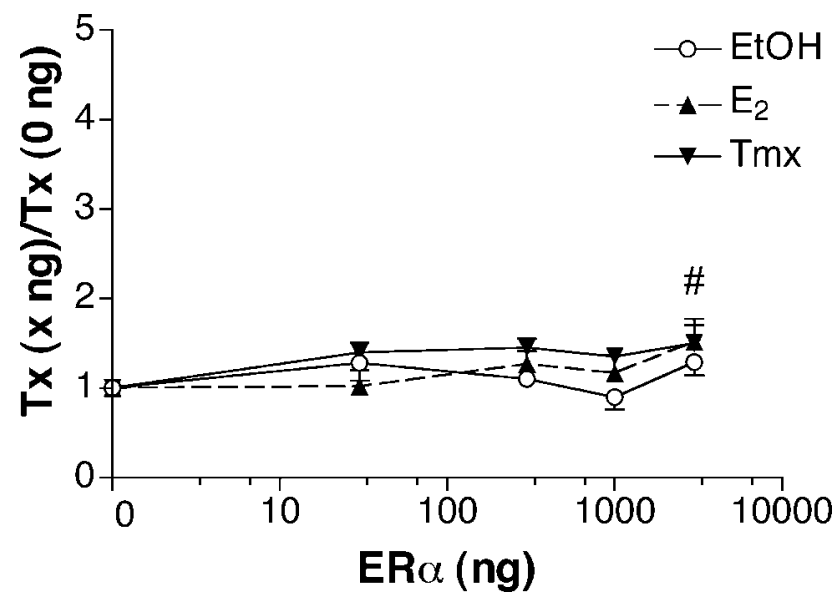

Figure 3. ER $\alpha$ modestly regulates the CRH promoter in a manner that is both ligand dependent and dependent on the amount of transfected ER $\alpha$ plasmid. Cells were treated with ethanolic vehicle, E2 $\left(10^{-7} \mathrm{M}\right)$, or $\operatorname{Tmx}\left(5 \times 10^{-6} \mathrm{M}\right)$ immediately after plating for $40-45 \mathrm{hr}$. The $y$-axis represents relative light units elicited by luciferase, divided by relative light units for $\beta$-galactosidase (to correct for efficiency of transfection). Data are expressed as a fold of the response to a given treatment at $0 \mathrm{ng}$ of transfected $\mathrm{ER} \alpha$. Thus, the response to transfection with empty expression vector for each treatment is 1 . The data represent the average of individual points from multiple experiments (total, $n=197$ determinations). Error bars represent the SEM. High levels of transfected ER $\alpha$ display a small degree of increased activity. The $n$-group was 22-46 per amount of ER $\alpha$ plasmid transfected. " indicates that the effect of transfecting $3000 \mathrm{ng}$ of $E R \alpha$ was greater than the effect of transfecting $0 \mathrm{ng}$ (1.43 vs 1.00). $\bigcirc$, $\mathrm{EtOH} ; \boldsymbol{\Delta}, \mathrm{E2} ; \boldsymbol{\nabla}, \mathrm{Tmx}$.

$\left(F_{(2,182)}=2.25 ; p=0.4543\right)$ or an interaction between the two $\left(F_{(8,182)}=0.60 ; p=0.2726\right)$. The $3000 \mathrm{ng}$ amount significantly differed from the $0 \mathrm{ng}$ group ( $p<0.050$ ), because at $3000 \mathrm{ng}$ of transfected $\mathrm{ER} \alpha$, the mean was $43 \%$ greater than that at $0 \mathrm{ng}$ (set treatment $\left(F_{(2,165)}=6.41 ; p=0.0021\right)$ and amount transfected $\left(F_{(4,165)}=7.85 ; p<0.0001\right)$ but no interaction $\left(F_{(8,165)}=0.86\right.$; $p=0.5541)$. There was a difference between treatment groups $(p<0.050)$. The E2 group differed from EtOH and Tmx; however, there was no difference between $\mathrm{EtOH}$ and $\mathrm{Tmx}$ groups. For amounts, the $0 \mathrm{ng}$ group differed from the 300,1000 , and $3000 \mathrm{ng}$ groups $(p<0.050)$. The $30 \mathrm{ng}$ group differed only from the 1000 ng group. Importantly, this isoform displayed a strong tendency to display constitutive activity; compare EtOH at $0 \mathrm{ng}$ with $\mathrm{EtOH}$ at $1000 \mathrm{ng}$ (Fig. 4A). Although the difference between these two points was not significant using the Bonferroni test $(p<0.050)$, it was using Fisher's LSD test $(p<0.050)$. As a control, ER $\beta 1$ was transfected either with the CRH promoter:reporter construct or with the empty vector, as were all the other ER $\beta$ expression vectors examined. The CRH promoter construct supported activation. As above, the corresponding signals for the vector control were all at the level of the mock transfection (data not shown). Thus, the effects we report here are mediated through the CRH promoter. Together, the data demonstrate a very different pattern of CRH transcriptional activation by ER $\beta 1$ compared with $\operatorname{ER} \alpha$. Thus, the degree to which $\operatorname{ER} \beta 1$ is expressed in a cell could determine the net response of the $\mathrm{CRH}$ gene to $\mathrm{ER} \beta 1$ in the absence of ligand or in the presence of a ligand, E2, or a selective estrogen receptor modulator (SERM) such as Tmx.

In contrast to $\mathrm{ER} \beta 1, \mathrm{ER} \beta 1 \delta 3$ supported a strong ligand effect at the $\mathrm{CRH}$ promoter (Fig. $4 \mathrm{~B}$ ). A two-way ANOVA revealed a strong and highly significant effect of treatment $\left(F_{(2,162)}=82.33\right.$; $p<0.0001)$, effects of amounts $\left(F_{(4,162)}=9.26 ; p<0.0001\right)$, and an interaction between the two $\left(F_{(8,162)}=7.15 ; p<0.0001\right)$. Pairwise analysis indicated that the E2 group differed from both the EtOH and Tmx groups; however, the Tmx and EtOH groups did not differ $(p<0.050)$. All amounts of transfected ER $\beta 1 \delta 3$ 

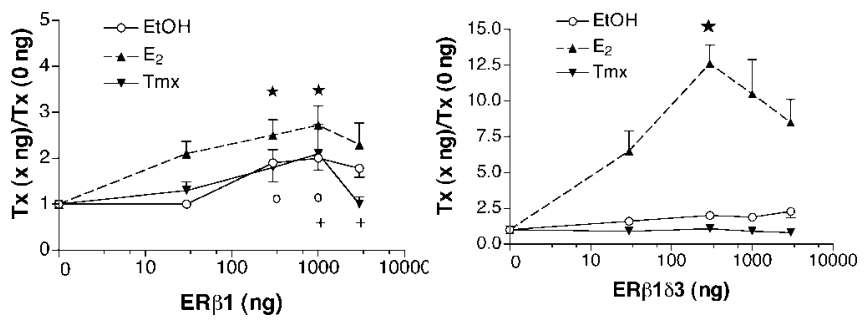

Figure 4. $\operatorname{ER} \beta 1$ displays constitutive activity, and $\operatorname{ER} \beta 1 \delta 3$ activity is ligand dependent. Data are analyzed and depicted as described in the legend to Figure 3. $A$, ER $\beta 1$ activates the CRH promoter in the presence of $\mathrm{E} 2$. The total number of points analyzed was $176(\mathrm{EtOH}, n=68 ; \mathrm{E} 2$, $n=62 ; \operatorname{Tmx}, n=46)$. $\star$, E2 at $300 \mathrm{ng}(n=16)$ and $1000 \mathrm{ng}(n=12)$ differs from all treatments at $0 \mathrm{ng}$; the $1000 \mathrm{ng}$ point differs from $\mathrm{Et} \mathrm{OH}$ at $30 \mathrm{ng}$ as well $(p<0.050) . \bigcirc,+$, Fisher's LSD indicated a significant difference between individual points $p<0.050)$. $\bigcirc$, EtOH treatment at 300 and $1000 \mathrm{ng}$ both differed from $\mathrm{E} 2$ at 0 and $30 \mathrm{ng}$. +, Imx at $1000 \mathrm{ng}$ differed from Tmx at 0 and $3000 \mathrm{ng}$; Tmx at $3000 \mathrm{ng}$ also differed from $E 2$ at $3000 \mathrm{ng}$ and Tmx at $1000 \mathrm{ng}$. $B$, The ER $\beta 1 \delta 3$ isoform displays strong E2 responsiveness. $\star$, E2 at $300 \mathrm{ng}(n=8)$ was 12.6 fold that of the E2 treatment at $0 \mathrm{ng}(n=15)$ and 6.4 -fold that of the EtOH treatment $(n=8)$ at $300 \mathrm{ng}$. Error bars represent SEM.
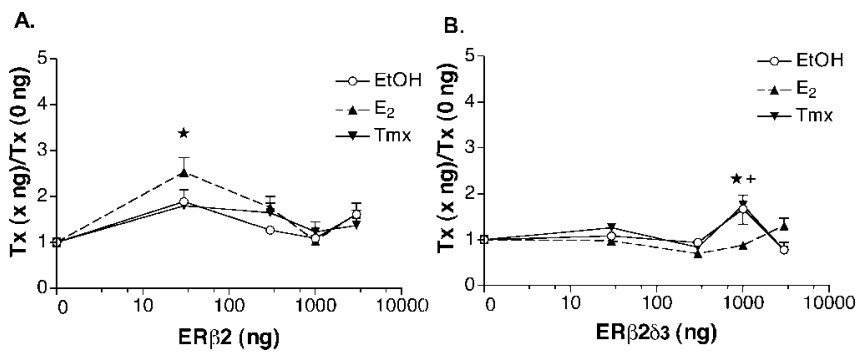

Figure 5. ER $\beta 2$ displays ligand-dependent activity, whereas $\operatorname{ER} \beta 2 \delta 3$ displays constitutive activity. Data are analyzed and depicted as described in the legend to Figure $3 . A, \star$, E2 at $30 \mathrm{ng}$ ( $n=12$ ) differed from EtOH at 0,300 , and $1000 \mathrm{ng}$, from E2 at $1000 \mathrm{ng}$, and from Tmx at 0 , 1000 , and $3000 \mathrm{ng} . n$ for these points ranged from $10-16$ per group. $B, E R \beta 2 \delta 3$ displays constitutive activity and ligand effects. The EtOH point at $1000 \mathrm{ng}(n=16)$ differs from the EtOH point at $0 \mathrm{ng}(n=20)$. $\star$, E2 at $1000(n=14)$ differed from both EtOH $(n=16)$ and $\operatorname{Tmx}(n=$ $11)$ at $1000 \mathrm{ng}$. + , Tmx treatment at $1000 \mathrm{ng}(n=11)$ differed from all EtOH treatment points ( $n=85)$ except that at $30 \mathrm{ng}(n=19)$, all E2 points $(n=86)$ except that at $3000 \mathrm{ng}(n=16)$, and all other Tmx treatment points ( $0 \mathrm{ng}, n=16 ; 300 \mathrm{ng}, n=11 ; 3000 \mathrm{ng}, n=11)$ except that at $30 \mathrm{ng}(n=15)$. Error bars represent SEM.

differed from the 0 ng group. Except for this, none differed from each other $(p<0.050)$. The E2 effect is striking: at $300 \mathrm{ng}$, the E2 treatment was 12.6 -fold of E2 at $0 \mathrm{ng}$ and approximately sixfold the $\mathrm{EtOH}$ treatment at $300 \mathrm{ng}$ (note the difference in the scale of the $y$-axis in this graph compared with all others). This point differed from all other EtOH and Tmx points and from E2 at 0 and $30 \mathrm{ng}(p<0.050)$. The response elicited was greater than those of all other ERs examined, ER $\alpha$ and the other three ER $\beta$ isoforms. In summary, the ER $\beta 1 \delta 3$ isoform is a strong, E2dependent activator of CRH transcription.

\section{$E R \beta 2$ and $E R \beta 2 \delta 3$}

ER $\beta 2$ isoforms contain an additional 18 amino acids in their LBDs (Fig. $1 B$ ). One would think that additional amino acids in this domain might compromise ligand-dependent ER regulation. Instead, ER $\beta 2$ supported an E2 response (Fig. 5A). A two-way ANOVA revealed that only the amount group contained significantly different points $\left(F_{(4,180)}=11.63 ; p<0.0001\right)$. There was no effect of treatment $\left(F_{(2,180)}=1.45 ; p<0.2377\right)$ and no interaction between treatment and amount $\left(F_{(8,180)}=1.02 ; p<\right.$ $0.4202)$. Analysis of pairs revealed a significant difference between the 30 ng group and all other amounts $(p<0.050)$. Furthermore, only the E2 point at 30 ng differed from other points, specifically: $\mathrm{EtOH}$ at 0, 300, 1000, and $3000 \mathrm{ng}$; Tmx at 0, 1000, and $3000 \mathrm{ng}$; and E2 at 0 and $1000 \mathrm{ng}$. Thus, E2 activation of the $\mathrm{CRH}$ promoter when bound to ER $\beta 2$ is ligand dependent only at a small amount of transfected plasmid. These data suggest that E2-bound ER $\beta 2$ only activates $\mathrm{CRH}$ at restricted levels of receptor.

As was the case for $\operatorname{ER} \beta 1$ and $\operatorname{ER} \beta 1 \delta 3$, lack of amino acids corresponding to the Exon 3 coding region changed the profile of ER $\beta 2$. Here, it conferred a degree of constitutive activity. A twoway ANOVA revealed no effect of treatment $\left(F_{(2,220)}=1.95 ; p=\right.$ $0.1450)$, a highly significant effect of amount of receptor transfected $\left(F_{(4,220)}=9.30 ; p<0.0001\right)$, and an interaction between the two $\left(F_{(8,220)}=4.80 ; p<0.0001\right)$. The 1000 ng group differed from all others, none of which differed from any group other than the 1000 ng group $(p<0.050)$. E2 restrained CRH transcriptional activity. This was most evident at $1000 \mathrm{ng}$, at which it was $52 \%$ of EtOH treatment $(p<0.050)$. E2 treatment also differed from Tmx treatment at this point. Tmx permitted increased transcription by $75 \%$ of the E2 response at $1000 \mathrm{ng}$ and $75 \%$ of Tmx at $0 \mathrm{ng}$. It did not differ from the EtOH response at $1000 \mathrm{ng}$. Thus, $\operatorname{ER} \beta 1 \delta 3$ was a phenotypic hybrid of $\operatorname{ER} \alpha$ and $\mathrm{ER} \beta 1$ at the CRH promoter. Like $\mathrm{ER} \alpha$, ligand effects were small. Like $\mathrm{ER} \beta 1$, $\mathrm{ER} \beta 2 \delta 3$ displayed constitutive activity; compare the EtOH response at 0 to $1000 \mathrm{ng}$ for each receptor (Figs. $4 A, 5 B$ ). Together, these data reveal a complex regulation of $\operatorname{ER} \beta$ activity by the amino acids coded for by Exon3 and the additional 18 amino acids found in ER $\beta 2$ isoforms.

\section{$\mathrm{ER} \boldsymbol{\beta}$ isoforms regulate transcription differently at $\mathrm{CRH}$ and AP-1}

It has been reported previously that the CRH promoter lacks palindromic EREs and also suggested that $\mathrm{ER} \alpha$ stimulates $\mathrm{CRH}$ activity via ERE half-sites (Vamvakopoulos and Chrousos, 1993). Another possibility is that ERs could be regulating CRH through an alternate pathway that involves a different transcription factor (e.g., through AP-1 sites). Because the CRH promoter contains several AP-1 and AP-1-like sites [Transcription Factor Database (TRANSFAC) analysis; data not shown], we sought to determine whether the behavior of ER $\beta 1$ and $\operatorname{ER} \beta 2$ at CRH was different from those at an AP- 1 site. We compared $\operatorname{ER} \beta$ behaviors at the $\mathrm{CRH}$ promoter with that of a highly studied AP-1-regulated promoter, Coll73 (Kushner et al., 2000). We did so in the same experiment using cells from the same passage. It was shown above that E2-dependent activation of the CRH promoter by ER $\beta 1$ is modest (Fig. 4A). Furthermore, at low doses, the more robust constitutive activity of $\operatorname{ER} \beta 1$ is not apparent. To elicit the more robust activity, we transfected cells with $1000 \mathrm{ng}$ of ER $\beta 1$. A one-way ANOVA revealed a significant effect of treatment $\left(F_{(2,34)}\right.$ $=4.68 ; p<0.0165)$. A one-way ANOVA for effect of receptor in the presence of $\mathrm{EtOH}$ (in the presence vs the absence of ER $\beta 1$ ) revealed significant constitutive activity (EtOH-treated groups, $\left.F_{(3,44)}=40.40 ; p<0.0001\right)$, as above; compare the EtOH group in the presence of receptor with the absence of receptor in Figure 6 to the EtOH group at 0 and $1000 \mathrm{ng}$ in Figure $4 \mathrm{~A}$. The pattern of Coll73 regulation by ER $\beta 1$ was as reported previously (Paech et al., 1997; Price et al., 2000). A one-way ANOVA revealed a highly significant effect of treatment $\left(F_{(2,31)} ; p<0.0001\right)$. E2 repressed activity seen in the presence of EtOH by $33 \%$, whereas Tmx increased it by $66 \%$. ER $\beta 2$ tended to act in a manner similar to $\mathrm{ER} \beta 1$ at these two promoters; however, the ligand effects were not significant (data not shown). This likely reflects the difficulty of optimizing the response of two stress-responsive promoters to two different ER $\beta$ isoforms simultaneously. Together, the data 


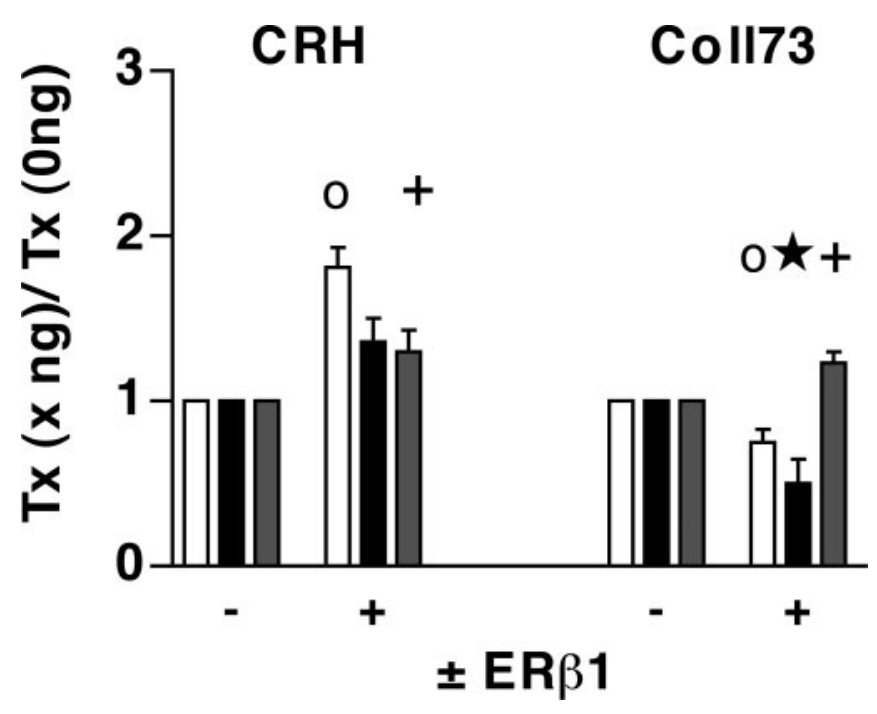

Figure 6. Ligand profiles of ER $\beta 1$ at the CRH versus those at an AP- 1 site. ER $\beta 1$ was cotransfected with either the CRH ( $1 \mu \mathrm{g}$ of ER) or AP-1 ( $5 \mu \mathrm{g}$ of ER) promoter constructs depicted in Figure $1 A$. The same passage of HeLa cells was transfected with either CRH or Coll73 along with $E R \beta 1$. $O$, At the CRH promoter (left), in the presence of $E R \beta 1$, there was an $81 \%$ increase in the $\mathrm{EtOH}$ group over the $\mathrm{EtOH}$ group in the absence of $\mathrm{ER} \beta 1$ ( $n=12$ for this and all $\mathrm{EtOH}$ groups). + , Imx significantly reduced the effect seen in the presence of $\mathrm{Et} O \mathrm{H}(n=12)$. $O$, At the Coll73 promoter (right), there was a $25 \%$ reduction of basal activity in the presence of $E R \beta 1$ without ligand ( $\mathrm{EtOH} ; n=12)$. $\star$, E2 was $50 \%$ of the E2 activity in the absence of ER (1.0). + , $\operatorname{Tmx}$ treatment increased activity by $24 \%$ compared with the Tmx activity in the absence of ER (1.0).

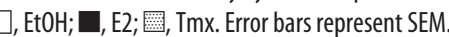

indicate that the dominant functional element targeted by ER $\beta$ in the $\mathrm{CRH}$ promoter $[(-663)-(+124)]$ is not an AP-1 site.

\section{Discussion}

Together, the data presented here corroborate the hypothesis that ERs regulate $\mathrm{CRH}$ in the PVH of the hypothalamus. ER $\beta$ immunoreactivity is present in $12 \%$ of IR CRH neurons in the parvocellular region. Additionally, all four ER $\beta$ isoforms are present in the PVH at the level of mRNA (Fig. 2). We do not know the extent to which $\mathrm{ER} \beta$ s play a role in $\mathrm{CRH}$ transcriptional regulation in vivo; $12 \%$ is a modest proportion. However, these animals were treated with colchicine, and it may be that in other conditions (e.g., ovariectomy combined with adrenalectomy) that the number of neurons labeled with both $\mathrm{ER} \beta$ and $\mathrm{CRH}$ would increase. Regardless, the finding of even a small population of neurons displaying $\mathrm{ER} \beta$ and $\mathrm{CRH}$, and an absence of $\mathrm{ER} \alpha$ staining in the medial parvocellular region, suggests that $\operatorname{ER} \beta$, rather than $\operatorname{ER} \alpha$, is poised to contribute to $\mathrm{CRH}$ transcriptional regulation involved in the stress response.

In keeping with our anatomical data, we found that $\operatorname{ER} \beta$ isoforms, rather than $\mathrm{ER} \alpha$, exert substantial regulation of the $\mathrm{CRH}$ promoter. The constitutive activity of $\mathrm{ER} \alpha$ described here differs from that reported previously. Previously, ER $\alpha$ was found to stimulate $\mathrm{CRH}$ to a small extent (two to three times) in the presence of E2 (Vamvakopoulos and Chrousos, 1993). The use of different promoters $(-2.4 \mathrm{~kb}-1)$ and cell lines (CV-1s) (Vamvakopoulos and Chrousos, 1993) may explain these differences. It is also possible, however, that the regulation reported previously and our observation of a small effect of ER $\alpha$ are attributable to the fact that $\mathrm{ER} \alpha$ is an inherently weak transcriptional activator at the $\mathrm{CRH}$ promoter. Together with our colocalization findings, our data suggest that the physiologically important $\mathrm{ER}(\mathrm{s})$ in $\mathrm{CRH}$ parvocellular neurons of the $\mathrm{PVH}$ are the $\mathrm{ER} \beta$ isoforms rather than the first identified $\mathrm{ER}, \operatorname{ER} \alpha$.
We do not yet know which ER $\beta$ isoform(s) are in CRH neurons, because available ER $\beta$ antibodies cannot distinguish between them. However, neurons of the PVH express a number of ER $\beta$ mRNA splice variants, as determined by PCR (Fig. $2 B$ ) (Price et al., 2000). Therefore, a given CRH neuron could express one or multiple isoforms of $\mathrm{ER} \beta$. The possibility of multiple isoform expression is relevant in that $\mathrm{ER} \beta$ isoforms have been shown to heterodimerize with themselves and with ER $\alpha$ (for review, see Pettersson and Gustafsson, 2001). This is a possible mechanism of $\mathrm{CRH}$ regulation that, although we have not yet studied, suggests the potential for a broad array of genomic responses in a hypothalamic paraventricular subpopulation of IR ER $\beta$ CRH parvocellular neurons.

$\mathrm{CRH}$ parvocellular neurons that regulate the stress response reside in an extremely complicated brain nucleus, the PVH. In fact, the parvocellular area alone has at least three subnuclei: medial, dorsal, and ventral (Swanson and Kuypers, 1980). Medial parvocellular neurons project to the median eminence (Merchenthaler et al., 1983; Swanson et al., 1983). This region contains $\mathrm{CRH}$ neurons that trigger the HPAA. The dorsal and ventral neurons project to autonomic nuclei in the brainstem (Swanson and Sawchenko, 1980). The neurons expressing both CRH and $\operatorname{ER} \beta$ (Fig. $2 A$, insert) are in the region of the medial parvocellular division; however, without combined retrograde tracing and immunocytochemistry, we cannot say with absolute certainty that they are the neuroendocrine motor neurons of the HPAA. Regardless, we believe that the finding of $\mathrm{ER} \beta$ in CRH parvocellular neurons combined with our data from transfection-reporter gene studies suggests that $\mathrm{ER} \beta$ isoforms play a role in maintaining homeostasis, be it through regulating the HPAA or the CNS component of the autonomic nervous system.

Our data bear on two aspects of ER-regulated CRH transcription: (1) structure-function correlates of $\operatorname{ER} \beta$ and (2) the nature of the ER $\beta$ regulatory pathway. With respect to structure-function correlates, absence of the region corresponding to Exon3 (the $\delta 3$ isoforms) had a striking effect on ER $\beta 1$ and ER $\beta 2$ phenotypes. Exon 3 codes for the second ER zinc-binding domain of the DBD. The DBD plays an important role in ERE-mediated and alternate pathways (Umayahara et al., 1994; Webb et al., 1995; Jakacka et al., 2001; Price et al., 2001; Bjornstrom and Sjoberg, 2002; Uht et al., 2004). At the CRH promoter, the $\delta 3$ splice variants substantially changed ligand responsiveness of ER $\beta 1$ and ER $\beta 2$ (Figs. 4, 5). The $\delta 3$ deletion converts ER $\beta 1$ from a receptor that exhibits constitutive activity (Fig. $4 A$ ) to one with activity that is predominantly ligand dependent (Fig. $4 B$ ). In the context of $\operatorname{ER} \beta 2$, the receptor is converted from a ligand-dependent transcription factor (Fig. 5A) to one that exhibited weak ligand responses and modest constitutive activity (Fig. $5 B$ ). Thus, the region encoded by ER $\beta$ Exon 3 plays a critical role in the ability of $\mathrm{ER} \beta 1$ and $\mathrm{ER} \beta 2$ to respond to ligand, as well as to display constitutive activity at the CRH promoter.

In considering pathways by which $\operatorname{ER} \beta$ could regulate the $\mathrm{CRH}$ promoter, an alternate (nonclassic) pathway of transcription can be invoked, because the CRH promoter does not contain full, palindromic EREs (Vamvakopoulos and Chrousos, 1993) [TRANSFAC analysis (Wingender et al., 1996); data not shown)]. It does contain AP-1 and AP-1-like sites. However, the observed ligand profiles for both $\mathrm{ER} \alpha$ and $\mathrm{ER} \beta$ isoforms fail to uniformly match previously established patterns of ER $\beta$-regulated AP- 1 activity (Paech et al., 1997; Price et al., 2001). In general, ER $\alpha$ stimulates the ER-AP-1 pathway in the presence of both estrogens and SERMs (e.g., Tmx). At the CRH promoter used here, there was no effect of treatment. ER $\beta 1$ and ER $\beta 2$ inhibit AP-1- 
activated transcription in the presence of estrogens and stimulate it in the presence of SERMs (Paech et al., 1997; Price et al., 2000). Here, E2 modestly stimulated transcription (Figs. $4 A$, $5 A$ ). In the presence of Tmx, the effects of ER $\beta 1$ and ER $\beta 2$ were minimal and inhibitory, when significant (Figs. $4 A, 5 A$ ). ER $\beta 1$ and two $\delta 3$ isoforms have been shown to reverse the profile of E2 and Tmx responses at an AP-1 site: E2 stimulates, and Tmx tends to inhibit, but not significantly so. As at an AP- 1 site, the ER $\beta 1 \delta 3$ isoform enhanced E2-stimulated CRH transcription and tended to inhibit CRH in the presence of Tmx (Fig. $4 B$ ). The ER $\beta 2 \delta 3$ isoform here, however, led to E2 restraint of transcriptional activity and no effect of Tmx. Together, the reported data (Price et al., 2000), our titration data, and the side-by-side comparison of the CRH promoter and the Coll73 promoter (Fig. 6) indicate that the ER $\beta$ isoforms studied do not regulate the CRH gene through a mechanism solely or predominantly mediated by an AP-1 site.

In addition to ER regulation mediated through AP-1 sites, $\mathrm{ER} \alpha$ and $\mathrm{ER} \beta$ also stimulate transcription through nonconsensus cAMP response elements (CREs), as shown in the CyclinD1 promoter (Liu et al., 2002). Like CyclinD1, the CRH promoter contains CRE and CRE-like elements. One in particular has been implicated consistently in $\mathrm{CRH}$ promoter regulation: that at position -232 to -215 (in human CRH) (Fig. 2A). This CRE mediates cAMP-stimulated transcription (Guardiola-Diaz et al., 1994) that is blocked by glucocorticoids (Guardiola-Diaz et al., 1996). Thus, it could be a target for estrogen regulation and/or a site of integration of information conveyed by the steroid hormone milieu.

The observations that the amplitude of the stress response is gender specific, that this specificity is estrogen mediated, and that disorders of HPAA regulation have a female preponderance raise the following question: could the opposing effects of estrogens and glucocorticoids on the HPAA be explained on a molecular basis, one that involves integration of these signals through the $\mathrm{CRH}$ promoter? It appears that the answer is yes. It has been shown that ERs and GRs modulate the effects of each other both through classic, ERE-mediated pathways (Meyer et al., 1989) and ER-AP-1 pathways (Uht et al., 1997). Furthermore, AP-1 family members and the CRE binding protein (CREB) share a common coactivator, the CREB binding protein (CBP) (Kwok et al., 1994; Vo and Goodman, 2001). We have evidence that ER transcriptional activation mediated through CBP (Webb et al., 1998; Kushner et al., 2000) is attenuated by GR (R. M. Uht, unpublished observations). Thus, it is quite possible that the CRE in the CRH promoter $(-232$ to -215$)$ is a node of integration for estrogen, glucocorticoid, and cAMP-regulated CRH expression. Thus, the findings presented here may shed light on mechanisms of an aspect of gender differences in the stress response and pathogenesis of HPAA disorders.

\section{References}

Bjornstrom L, Sjoberg M (2002) Mutations in the estrogen receptor DNAbinding domain discriminate between the classical mechanism of action and cross-talk with Stat5b and activating protein 1 (AP-1). J Biol Chem 277:48479-48483.

Brotman AW (2001) Eating disorders. In: Psychiatric secrets, Ed 2 (Jacobson JL, Jacobson AM, eds), p 137. Philadelphia: Hanley and Belfus.

Burgess LH, Handa RJ (1992) Chronic estrogen-induced alterations in adrenocorticotropin and corticosterone secretion, and glucocorticoid receptormediated functions in female rats. Endocrinology 131:1261-1269.

Chomczynski P, Sacchi N (1987) Single step method of RNA isolation by acid guanidinium thiocyanate-phenol chloroform extraction. Anal Biochem 162:156-159.

Cintra A, Fuxe K, Harfstrand A, Agnati LF, Wikstrom AC, Okret S, Vale W, Gustafsson JA (1987) Presence of glucocorticoid receptor immunoreac- tivity in corticotrophin releasing factor and in growth hormone releasing factor immunoreactive neurons of the rat di- and telencephalon. Neurosci Lett 77:25-30.

Gaub MP, Bellard M, Scheuer I, Chambon P, Sassone-Corsi P (1990) Activation of the ovalbumin gene by the estrogen receptor involves the fos-jun complex. Cell 63:1267-1276.

Gold P, Loriaux D, Roy A, Kling M, Calabrese J, Kellner C, Nieman L, Post R, Pickar D, Gallucci W, Avgerinos P, Paul S, Oldfield E, Cutler Jr G, Chrousos G (1986a) Responses to corticotropin-releasing hormone in the hypercortisolism of depression and Cushing's disease. N Engl J Med 314:1329-1335.

Gold PW, Gwirtsman H, Avgerinos PC, Nieman LK, Gallucci WT, Kaye W, Jimerson D, Ebert M, Rittmaster R, Loriaux DL (1986b) Abnormal hypothalamic-pituitary-adrenal function in anorexia nervosa. Pathophysiologic mechanisms in underweight and weight-corrected patients. N Engl J Med 314:1335-1342.

Guardiola-Diaz HM, Boswell C, Seasholtz AF (1994) The cAMP-responsive element in the corticotropin-releasing hormone gene mediates transcriptional regulation by depolarization. J Biol Chem 269:14784-14791.

Guardiola-Diaz HM, Kolinske JS, Gates LH, Seasholtz AF (1996) Negative glucocorticoid regulation of cyclic adenosine $3^{\prime}, 5^{\prime}$-monophosphatestimulated corticotropin-releasing hormone-reporter expression in AtT-20 cells. Mol Endocrinol 10:317-329.

Jakacka M, Ito M, Weiss J, Chien PY, Gehm BD, Jameson JL (2001) Estrogen receptor binding to DNA is not required for its activity through the nonclassical AP1 pathway. J Biol Chem 276:13615-13621.

Kerr JE, Allore RJ, Beck SG, Handa RJ (1995) Distribution and hormonal regulation of androgen receptor (AR) and AR messenger ribonucleic acid in the rat hippocampus. Endocrinology 136:3213-3221.

Kuiper GG, Enmark E, Pelto-Huikko M, Nilsson S, Gustafsson JA (1996) Cloning of a novel receptor expressed in rat prostate and ovary. Proc Natl Acad Sci USA 93:5925-5930.

Kushner PJ, Agard DA, Greene GL, Scanlan TS, Shiau AK, Uht RM, Webb P (2000) Estrogen receptor pathways to AP-1. J Steroid Biochem Mol Biol 74:311-317.

Kwok RP, Lundblad JR, Chrivia JC, Richards JP, Bachinger HP, Brennan RG, Roberts SG, Green MR, Goodman RH (1994) Nuclear protein CBP is a coactivator for the transcription factor CREB. Nature 370:223-226.

LaFlamme N, Nappi RE, Drolet G, Labrie C, Rivest S (1998) Expression and neuropeptidergic characterization of estrogen receptors (ERalpha and ERbeta) throughout the rat brain: anatomical evidence of distinct roles of each subtype. J Neurobiol 36:357-378.

Liposits Z, Uht R, Harrison R, Gibbs F, Paull W, Bohn M (1987) Ultrastructural localization of glucocorticoid receptor (GR) in hypothalamic paraventricular neurons synthesizing corticotropin-releasing factor (CRF). Histochemistry 87:407-412.

Liu MM, Albanese C, Anderson CM, Hilty K, Webb P, Uht RM, Price Jr RH, Pestell RG, Kushner PJ (2002) Opposing action of estrogen receptors alpha and beta on cyclin D1 gene expression. J Biol Chem 277:24353-24360.

Merchenthaler I, Vigh S, Petrusz P, Schally A (1983) The paraventriculoinfundibular corticotropin releasing factor (CRF) pathway as revealed by immunocytochemistry in long-term hypophysectomized or adrenalectomized rats. Regul Pept 5:295-305.

Meyer ME, Gronemeyer H, Turcotte B, Bocquel MT, Tasset D, Chambon P (1989) Steroid hormone receptors compete for factors that mediate their enhancer function. Cell 57:433-442.

Mitra SW, Hoskin E, Yudkovitz J, Pear L, Wilkinson HA, Hayashi S, Pfaff DW, Ogawa S, Rohrer SP, Schaeffer JM, McEwen BS, Alves SE (2003) Immunolocalization of estrogen receptor beta in the mouse brain: comparison with estrogen receptor alpha. Endocrinology 144:2055-2067.

Osterlund M, Kuiper G, Gustafsson J, Hurd Y (1998) Differential distribution and regulation of estrogen receptor-alpha and -beta mRNA within the female rat brain. Brain Res Mol Brain Res 54:175-180.

Pacak K, Palkovits M (2001) Stressor specificity of central neuroendocrine responses: implications for stress-related disorders. Endocr Rev 22:502-548.

Paech K, Webb P, Kuiper GG, Nilsson S, Gustafsson J, Kushner PJ, Scanlan TS (1997) Differential ligand activation of estrogen receptors ERalpha and ERbeta at AP1 sites. Science 277:1508-1510.

Palkovits M, Brownstein MJ, Vale W (1985) Distribution of corticotrophin releasing factor in rat brain. Fed Proc 44:215-219.

Patisaul HB, Whitten PL, Young LJ (1999) Regulation of estrogen receptor 
beta mRNA in the brain: opposite effects of 17-beta estradiol and the phytoestrogen, coumestrol. Brain Res Mol Brain Res 67:165-171.

Petersen DN, Tkalcevic GT, Koza-Taylor PH, Turi TG, Brown TA (1998) Identification of estrogen receptor beta2, a functional variant of estrogen receptor beta expressed in normal rat tissues. Endocrinology 139:1082-1092.

Petersson K, Gustafsson JA (2001) Role of estrogen receptor beta in estrogen action. Annu Rev Physiol 63:165-192.

Price Jr RH, Lorenzon N, Handa RJ (2000) Differential expression of estrogen receptor beta splice variants in rat brain: identification and characterization of a novel variant missing exon 4. Brain Res Mol Brain Res 80:260-268.

Price Jr RH, Butler C, Webb P, Uht R, Kushner P, Handa RJ (2001) A splice variant of estrogen receptor beta missing exon 3 displays altered subnuclear localization and capacity of transcriptional activation. Endocrinology 142:2039-2049.

Shughrue PJ, Lane MV, Merchenthaler I (1997) Comparative distribution of estrogen receptor-alpha and -beta mRNA in the rat central nervous system. J Comp Neurol 388:507-525.

Solum D, Handa R (2002) Estrogen regulates the development of brainderived neurotrophic factor mRNA and protein in the rat hippocampus. J Neurosci 22:2650-2659.

Suzuki S, Handa RJ (2004) Regulation of estrogen receptor-beta expression in the female rat hypothalamus: differential effects of dexamethasone and estradiol. Endocrinology 145:3658-3670.

Swanson LW, Kuypers HG (1980) The paraventricular nucleus of the hypothalamus: cytoarchitectonic subdivisions and organization of projections to the pituitary, dorsal vagal complex, and spinal cord as demonstrated by retrograde fluorescence double-labeling methods. J Comp Neurol 194:555-570.

Swanson LW, Sawchenko PE (1980) Paraventricular nucleus: a site for the integration of neuroendocrine and autonomic mechanisms. Neuroendocrinology 31:410-417.

Swanson L, Sawchenko P, Rivier J, Vale W (1983) Organization of ovine corticotropin-releasing factor immunoreactive cells and fibers in the rat brain: an immunohistochemical study. Neuroendocrinology 36:165-186.

Uht RM, McKelvy JF, Harrison RW, Bohn MC (1988) Demonstration of glucocorticoid receptor-like immunoreactivity in glucocorticoidsensitive vasopressin and corticotropin-releasing factor neurons in the hypothalamic paraventricular nucleus. J Neurosci Res 19:405-411.

Uht RM, Anderson CM, Webb P, Kushner PJ (1997) Transcriptional activities of estrogen and glucocorticoid receptors are functionally integrated at the AP-1 response element. Endocrinology 138:2900-2908.

Uht RM, Webb P, Nguyen P, Price Jr RH, Valentine C, Favre H, Kushner PJ (2004) A conserved lysine in the estrogen receptor DNA binding domain regulates ligand activation profiles at AP-1 sites, possibly by controlling interactions with a modulating repressor. Nucl Recept 2:2.

Umayahara Y, Kawamori R, Watada H, Imano E, Iwama N, Morishima T, Yamasaki Y, Kajimoto Y, Kamada T (1994) Estrogen regulation of the insulin-like growth factor I gene transcription involves an AP-1 enhancer. J Biol Chem 269:16433-16442.

Vale W, Spiess J, Rivier C, Rivier J (1981) Characterization of a 41-residue ovine hypothalamic peptide that stimulates secretion of corticotropin and $\beta$-endorphin. Science 213:1394-1397.

Vamvakopoulos NC, Chrousos GP (1993) Evidence of direct estrogenic regulation of human corticotropin-releasing hormone gene expression. J Clin Invest 92:1896-1902.

Vo N, Goodman R (2001) CREB-binding protein and p300 in transcriptional regulation. J Biol Chem 276:13505-13508.

Webb P, Lopez GN, Uht RM, Kushner PJ (1995) Tamoxifen activation of the estrogen receptor/AP-1 pathway: potential origin for the cell-specific estrogen-like effects of antiestrogens. Mol Endocrinol 9:443-456.

Webb P, Nguyen P, Shinsako J, Anderson C, Feng W, Nguyen MP, Chen D, Huang SM, Subramanian S, McKinerney E, Katzenellenbogen BS, Stallcup MR, Kushner PJ (1998) Estrogen receptor activation function 1 works by binding p160 coactivator proteins. Mol Endocrinol 12:1605-1618.

Wingender E, Dietze P, Karas H, Knuppel R (1996) TRANSFAC: a database on transcription factors and their DNA binding sites. Nucleic Acids Res 24:238-241.

Wulsin LR (2001) Depressive disorders. In: Psychiatric secrets, Ed 2 (Jacobson JL, Jacobson AM, eds), p 71. Philadelphia: Hanley and Belfus. 